\title{
Two common nonsynonymous paraoxonase 1 (PON1) gene polymorphisms and brain astrocytoma and meningioma
}

\author{
Carmen Martínez ${ }^{1}$, José A Molina ${ }^{2}$, Hortensia Alonso-Navarro ${ }^{3,4}$, Félix J Jiménez-Jiménez ${ }^{3}$, José AG Agúndez ${ }^{1}$, \\ Elena García-Martín $5^{*}$
}

\begin{abstract}
Background: Human serum paraoxonase 1 (PON1) plays a major role in the metabolism of several organophosphorus compounds. The enzyme is encoded by the polymorphic gene PON1, located on chromosome 7q21.3. Aiming to identify genetic variations related to the risk of developing brain tumors, we investigated the putative association between common nonsynonymous PON1 polymorphisms and the risk of developing astrocytoma and meningioma.
\end{abstract}

Methods: Seventy one consecutive patients with brain tumors (43 with astrocytoma grade II/III and 28 with meningioma) with ages ranging 21 to 76 years, and 220 healthy controls subjects were analyzed for the frequency of the nonsynonymous PON1 genotypes L55M rs854560 and Q192R rs662. All participants were adult Caucasian individuals recruited in the central area of Spain.

Results: The frequencies of the PON1 genotypes and allelic variants of the polymorphisms PON1 L55M and PON1 Q192R did not differ significantly between patients with astrocytoma and meningioma and controls. The minor allele frequencies were as follows: PON1 55L, 0.398, 0.328 and 0.286 for patients with astrocytoma, meningioma and control individuals, respectively; PON1 192R, 0.341, 0.362 and 0.302 for patients with astrocytoma, meningioma and control individuals, respectively. Correction for age, gender, or education, made no difference in odds ratios and the $p$ values remained non-significant. Haplotype association analyses did not identify any significant association with the risk of developing astrocytoma or meningioma.

Conclusions: Common nonsynonymous PON1 polymorphisms are not related with the risk of developing astrocytoma and meningioma.

\section{Background}

Primary cancers of the brain and nervous system globally account for nearly 200,000 new cases per year, the highest rates being observed in developed areas [1]. The two most common histologic types of brain tumors in adults are gliomas and meningiomas, and data suggest that gliomas are more common in men, while meningiomas occur more often in women [2].

The etiology of brain tumors is still poorly understood. Despite some studies suggested a possible

\footnotetext{
* Correspondence: elenag@unex.es

${ }^{5}$ Department of Biochemistry and Molecular Biology and Genetics, University of Extremadura, Avda de Elvas s/n, 06071, Badajoz, Spain

Full list of author information is available at the end of the article
}

relationship between the risk for brain tumors and several occupational and environmental exposures, including farming [3-5] and pesticides and/or herbicides [2,5-10], others failed to show this association [11-13]. A recent multicenter case-control study examining incident glioma and meningioma risk associated with occupational exposure to insecticides and herbicides showed increased risk for meningioma in women who reported ever using pesticides, with a trend of increasing risk with increasing years of herbicide exposure [14]. Interestingly, it has been reported that, in experimental models, organophosphorus insecticides and their oxons can affect astroglial cell proliferation in cultures of astrocytoma-glioma cell lines or primary astrocytes $[15,16]$.

\section{() Biomed Central}


Human serum paraoxonase 1 (PON1), a enzyme encoded by the polymorphic gene PON1 on chromosome $7 \mathrm{q} 21.3$, is an aryldialkylphosphatase, synthesized mainly in the liver, that plays a major role in the metabolism of several organophosphorus compounds, like some insecticides, neurotoxins, and arylesters [17]. The high variability in the activity of PON1 has been attributed to several polymorphisms within the gene, as well as physiological and pathological states, dietary and lifestyle factors and environmental chemicals. Two nonsynonymous polymorphisms, a leucine to methionine substitution at position 55 (L55M, rs854560, c.220 T > A according to the GenBank accession number NM 000446) and a glutamine to arginine substitution at position 192 (Q192R, rs662, c.632 A > G according to the GenBank accession number NM 000446), 8638 bp apart, have been shown to influence PON1 activity [18-20]. The $M$ allele at position 55 causes a decrease in protein stability [21] and the Q allele at position 192 has been associated with decreased metabolic activity for some substrates [22,23]. In the serum, PON1 is associated with high density lipoprotein (HDL), and plays an important role in lipid metabolism as an antioxidant molecule through several mechanisms [24-26]. In addition, PON1 is implicated in the elimination of carcinogenic lipid-soluble radicals from lipid peroxidation [27].

Although astrocytoma and meningioma arise from completely different types of cells, it cannot be ruled out that some similar features may be involved in their etiology. In some cases meningiomas can mimic astrocytomas and vice-versa and some studies reported concurrent occurrence of both tumors in the same patient [28-35]. Moreover, genetic and non-genetic risk factors have been associated with both types of tumors $[36,37]$. To establish whether PON1 genotype and allelic variants could be related to the risk of developing brain astrocytoma and/or meningioma, we have compared the prevalence of the PON1-L55M and PON1- Q192R polymorphisms in the PON1 gene, in a group of 71 patients with these brain tumors (43 with astrocytoma grade II/ III and 28 with meningioma), and 220 healty controls.

\section{Methods}

We studied 43 unrelated patients with brain astrocytoma grade II/III (26 men, 17 women; mean \pm SD age $51.7 \pm 17.4$ years) and 28 with brain meningioma (6 men, 22 women; mean \pm SD age $62.1 \pm 11.7$ years). The age ranges were 21-68 years for astrocytoma and 27-76 years for meningiomas. All consecutive patients attending the participating hospitals (Hospital Universitario "Doce de Octubre" (Madrid, Spain) and the Hospital Universitario Infanta Cristina (Badajoz, Spain)) between 1997 and 1999 that were diagnosed of astrocytoma grade II/III or brain meningioma were included in the study, and none was excluded for any reason. Diagnosis was confirmed by histologic analysis in all patients. These patients participated in a previous study by our group [38]. The control group was composed of 220 healthy unrelated Caucasian Spanish individuals (110 men and 110 women, most of them students or staff from the University of Extremadura and from the participating hospitals). The inclusion criteria were the following: age over 18 and lack of all the exclusion criteria. Exclusion criteria were history of neurological, gastrointestinal, liver or renal disease. The control group had a mean age of $44.5 \pm 12.2$ years.

All the participants were Caucasian Spanish individuals from the central area of Spain, and were included in the study after giving written informed consent. The protocol was approved by the Ethics Committees of the Hospital Universitario "Doce de Octubre" (Madrid, Spain) and the Hospital Universitario Infanta Cristina (Badajoz, Spain).

A $10 \mathrm{~mL}$ venous blood sample was obtained from each individual, collected in EDTA tubes and stored at $-80^{\circ} \mathrm{C}$ until analysis. Genomic DNA was isolated from leukocytes by means of standard procedures. PON1 genotyping was carried out by TaqMan assay designed to detect the following SNPs: PON1 L55M, rs854560 and Q192R, rs662 (C___2259750_20 and C___2548962_20, respectively, Applied Biosciences Hispania, Alcobendas, Madrid, Spain). The detection was carried out by qPCR in a Eppendorf realplex thermocycler by using fluorescent probes. The amplification conditions were as follows: After a denaturation time of $10 \mathrm{~min}$ at $96^{\circ} \mathrm{C}$, 45 cycles of $92^{\circ} \mathrm{C} 15 \mathrm{sec} 60^{\circ} \mathrm{C} 90 \mathrm{sec}$ were carried out and fluorescence was measured at the end of every cycle and at endpoint. All samples were determined by triplicate and genotypes were assigned both, by the gene identification software (RealPlex 2.0, Eppendorf) and by analysis of the reference cycle number for each fluorescence curve, calculated by the use of CalQPlex algorithm (Eppendorf). For every polymorphism tested, genomic DNA of twenty individuals carrying no mutations, twenty heterozygotes and twenty homozygotes were analyzed, by amplification-restriction as described elsewhere [39-41] and in all cases the genotypes fully corresponded with those detected with fluorescent probes.

The intergroup comparison values and the significance of the gene-dose effect were calculated by using the chisquare test or the Fisher's exact test when appropriate. Logistic regression was performed to verify that age, gender or education did not modify the odds ratios. Statistical analyses were performed using the SPSS 15.0 for Windows (SPSS Inc., Chicago, Illinois, USA). The patient's sample size was determined from allele frequencies observed for healthy individuals with a genetic model analyzing the frequency for carriers of the disease 
gene. Hardy-Weinberg equilibrium (HWE) was analyzed with the DeFinetti program (http://ihg2.helmholtzmuenchen.de/cgi-bin/hw/hwa1.pl). Haplotype reconstruction was carried out using the program PHASE v2.1.1 with the default model for recombination rate variation [42]. Seven independent runs with 1000 iterations, 500 burn-in iterations and a thinning interval of 1 were performed as described elsewhere [43]. Association tests were carried out with the software package PLINK [44].

\section{Results}

No departures from HWE were observed. The $p$ values (Pearson) for HWE departures were as follows: PON1 L55M: cases, $\mathrm{p}=0.620$, controls, 0.142; PON1 Q192R: cases, $\mathrm{p}=0.962$, controls, $\mathrm{p}=0.544$. The frequencies of PON1 genotypes and PON1 alleles in patients with brain tumors did not differ significantly from those of controls, both considering astrocytoma plus meningioma cases (Table 1), or astrocytoma and meningioma separately (Table 2). Different genetic models were used to test the genotypic associations. For overall patients the results for association tests for the PON1 L55M polymorphism were as follows: Genotypic test, $\mathrm{p}=0.879$; trend test, $\mathrm{p}=0.691$, dominant model, $\mathrm{p}=0.847$, recessive model $\mathrm{p}=0.612$. Regarding the results for association tests for the PON1 Q192R polymorphism in overall patients were: Genotypic test, $\mathrm{p}=0.542$; trend test, $\mathrm{p}=$ 0.282 , dominant model, $\mathrm{p}=0.279$, recessive model $\mathrm{p}=$ 0.567 . For astrocytoma patients the results for association tests for the PON1 L55M polymorphism were as follows: Genotypic test, $\mathrm{p}=0.989$; trend test, $\mathrm{p}=0.886$, dominant model, $\mathrm{p}=0.884$, recessive model $\mathrm{p}=0.932$. Regarding the PON1 Q192R polymorphism, the association test results were: Genotypic test, $\mathrm{p}=0.727$; trend test, $\mathrm{p}=0.465$, dominant model, $\mathrm{p}=0.424$, recessive model $\mathrm{p}=0.778$. For meningioma patients the results for association tests for the PON1 L55M polymorphism were as follows: Genotypic test, $\mathrm{p}=0.605$; trend test, $\mathrm{p}=0.386$, dominant model, $\mathrm{p}=0.605$, recessive model $\mathrm{p}=0.323$. Regarding the PON1 Q192R polymorphism, the association test results were: Genotypic test, $\mathrm{p}=0.649$; trend test, $\mathrm{p}=0.353$, dominant model, $\mathrm{p}=0.395$, recessive model $\mathrm{p}=0.524$. We tested also the frequencies for haplotypes and the $\mathrm{P}$ values for overall patients, astrocytoma patients and meningioma patients, respectively, were as follows: PON1 55L+192Q, 0.648, 0.945 and $0.384 ;$ PON1 55L+192R, 0.568, 0.721 and 0.557; PON1 55M+192Q, 0.560, 0.472 and 0.936; PON1 $55 \mathrm{M}+192 \mathrm{R}, 0.291,0.515$ and 0.318 .

Correction for age, gender, or education, made no difference in odds ratios and the $\mathrm{p}$ values remained non-significant.

\section{Discussion}

The brain is partially protected from chemical insults by a physical barrier mainly formed by the cerebral microvasculature, which prevents penetration of hydrophilic molecules into the cerebral extracellular space [45]. However, several drugs and environmental pollutants, including organophosphorus insecticides or other xenobiotics could reach the brain. This organ possesses an enzymatic equipment able to metabolize xenobiotics, like an entirely functional cytochrome P450 mono-oxygenase system in rodents and humans that would metabolise xenobiotics resulting in the formation of reactive and toxic metabolites in the neuronal cells [46]. Present mainly in the liver and blood, PON1 should hypothetically act as a detoxifying enzyme at this level, causing the hydrolysis of the acetylcholinesterase-inhibiting

Table 1 PON1 genotype and allelic variants of patients with brain tumor (BT) and healthy volunteers

\begin{tabular}{|c|c|c|c|}
\hline & BT PATIENTS ( $\mathrm{N}=73,146$ chromosomes) & CONTROLS ( $\mathrm{N}=220,440$ chromosomes) & OR $(95 \% \mathrm{Cl}) ; \mathrm{P}$ \\
\hline \multicolumn{4}{|l|}{ GENOTYPES } \\
\hline PON1 55 Leu/Leu & $11(15.1)[6.9-23.3]$ & 38 (17.3) [12.3-22.3] & $0.85(0.41-1.75) ; 0.662$ \\
\hline PON1 55 Leu/Met & $32(43.8)[32.5-55.2]$ & $94(42.7)$ [36.2-49.3] & - \\
\hline PON1 55 Met/Met & $30(41.1)[29.8-52.4]$ & $88(40.0)[33.5-46.5]$ & $1.05(0.61-1.79) ; 0.869^{2}$ \\
\hline PON1 $192 \mathrm{Gln} / \mathrm{G} \ln$ & $31(42.5)[31.1-53.8]$ & 109 (49.5) [42.9-56.2] & $0.75(0.44-1.28) ; 0.295^{1}$ \\
\hline PON1 192 Gln/Arg & $33(45.2)[33.8-56.6]$ & $89(40.5)$ [34.0-46.9] & - \\
\hline PON1 192 Arg/Arg & 9 (12.3) [4.8-19.9] & $22(10.0)[6.0-14.0]$ & $1.27(0.57-2.85) ; 0.576^{2}$ \\
\hline \multicolumn{4}{|l|}{ ALLELES } \\
\hline PON1 55 Leu & $54(37.0)[29.2-44.8]$ & 170 (38.6) [34.1-43.2] & $0.93(0.63-1.37) ; 0.722^{3}$ \\
\hline PON1 55 Met & $92(63.0)[55.2-70.8]$ & $270(61.4)[56.8-65.9]$ & - \\
\hline PON1 $192 \mathrm{Gln}$ & 95 (65.1) [57.3-72.8] & 307 (69.8) [65.5-74.1] & - \\
\hline PON1 $192 \mathrm{Arg}$ & $51(34.9)[27.2-42.7]$ & $133(30.2)[25.9-34.5]$ & $1.24(0.84-1.84) ; 0.289^{3}$ \\
\hline
\end{tabular}

The values in each cell represent: number (percentage) and [95\% confidence intervals]. ${ }^{1}$ The OR was calculated by using the dominant model. ${ }^{2}$ The OR was calculated by using the recessive model. ${ }^{3}$ The OR was calculated by using the allelic model. Test for trend with the number of variant alleles: PON 155 Leu/Met: $\mathrm{H}=0.0957 \mathrm{df}=1 \mathrm{p}=0.7570 ;$ PON1 $192 \mathrm{Gln} /$ Arg: $\mathrm{H}=1.1416 \mathrm{df}=1 \mathrm{p}=0.2853$. 
Table 2 PON1 genotype and allelic variants of patients with different types of brain tumor

\begin{tabular}{|c|c|c|c|c|}
\hline & $\begin{array}{l}\text { Astrocytoma ( } \mathrm{N}=44,88 \\
\text { chromosomes) }\end{array}$ & OR $(95 \% \mathrm{Cl}) ; \mathrm{P}$ & $\begin{array}{l}\text { Meningioma ( } \mathrm{N}=29,58 \\
\text { chromosomes) }\end{array}$ & OR $(95 \% \mathrm{Cl}) ; \mathrm{P}$ \\
\hline \multicolumn{5}{|l|}{ GENOTYPES } \\
\hline PON1 55 Leu/Leu & $8(18.2)$ [6.8-29.6] & $\begin{array}{l}1.07(0.47-2.43) ; \\
0.885^{1}\end{array}$ & $3(10.3)[0-21.4]$ & $\begin{array}{l}0.55(0.17-1.81) \\
0.345^{1}\end{array}$ \\
\hline PON1 55 Leu/Met & 19 (43.2) [28.5-57.8] & - & $13(44.8)[26.7-62.9]$ & - \\
\hline $\begin{array}{l}\text { PON1 } 55 \text { Met/ } \\
\text { Met }\end{array}$ & 17 (38.6) [24.2-53.0] & $\begin{array}{l}0.94(0.49-1.82) ; \\
0.866^{2}\end{array}$ & $13(44.8)$ [26.7-62.9] & $\begin{array}{l}1.22(0.57-2.62) \\
0.619^{2}\end{array}$ \\
\hline $\begin{array}{l}\text { PON1 } 192 \mathrm{Gln} / \\
\text { Gln }\end{array}$ & $19(43.2)[28.5-57.8]$ & $\begin{array}{l}0.77(0.41-1.48) ; \\
0.442^{1}\end{array}$ & $12(41.4)[23.5-59.3]$ & $\begin{array}{l}0.72(0.33-1.56) ; \\
0.409^{1}\end{array}$ \\
\hline $\begin{array}{l}\text { PON1 } 192 \mathrm{Gln} / \\
\text { Arg }\end{array}$ & $20(45.5)[30.7-60.2]$ & - & $13(44.8)$ [26.7-62.9] & - \\
\hline $\begin{array}{l}\text { PON1 } 192 \mathrm{Arg} / \\
\text { Arg }\end{array}$ & 5 (11.4) [2.0-20.7] & $\begin{array}{l}1.15(0.43-3.14) ; \\
0.786^{2}\end{array}$ & $4(13.8)[1.2-26.3]$ & $\begin{array}{l}1.44(0.48-4.34) ; \\
0.531^{2}\end{array}$ \\
\hline \multicolumn{5}{|l|}{ ALLELES } \\
\hline PON1 55 Leu & 35 (39.8) [29.5-50.0] & $\begin{array}{l}1.05(0.66-1.67) ; \\
0.842^{3}\end{array}$ & 19 (32.8) [20.7-44.8] & $\begin{array}{l}0.77(0.44-1.38) ; \\
0.386^{3}\end{array}$ \\
\hline PON1 55 Met & $53(60.2)$ [50.0-70.5] & - & 39 (67.2) [55.2-79.3] & - \\
\hline PON1 192 Gln & $58(65.9)$ [56.0-75.8] & - & $37(63.8)$ [51.4-76.2] & - \\
\hline PON1 192 Arg & 30 (34.1) [24.2-44.0] & $\begin{array}{l}1.19(0.74-1.94) ; \\
0.474^{3}\end{array}$ & $21(36.2)$ [23.8-48.6] & $\begin{array}{l}1.31(0.74-2.31) ; \\
0.355^{3}\end{array}$ \\
\hline
\end{tabular}

The values in each cell represent: number (percentage) and [95\% confidence intervals]. ${ }^{1}$ The OR was calculated by using the dominant model. ${ }^{2}$ The OR was calculated by using the recessive model. ${ }^{3}$ The OR was calculated by using the allelic model. Test for trend with the number of variant alleles: Astrocytoma PON1 55 Leu/Met: $\mathrm{H}=0.0360 \mathrm{df}=1 \mathrm{p}=0.8496 ;$ PON1 $192 \mathrm{Gln} / \mathrm{Arg}: \mathrm{H}=0.5537 \mathrm{df}=1 \mathrm{p}=0.4568$. Meningioma PON1 55 Leu/Met: $\mathrm{H}=0.5987 \mathrm{df}=1 \mathrm{p}=0.4391 ; \mathrm{PON} 1$ $192 \mathrm{Gln} / \mathrm{Arg}: \mathrm{H}=0.8057 \mathrm{df}=1 \mathrm{p}=0.3694$.

oxons (activated intermediates) of some organophosphorus compounds $[47,48]$, decreasing the possible arrive of these compounds to the brain. Several evidences point to pesticides as risk a factor for brain tumors $[49,50]$. PON1 plays a prominent role among the enzymes that prevent or mitigate damage caused by reactive oxygen species. And hence it is conceivable that changes in PON1 activity due to nonsynonymous polymorphisms may modulate the risk to develop brain tumors.

Published evidences make it difficult to determine $a$ priori which PON1 isoform represents a risk factor for the development of brain tumors. Although initial findings point to the PON1-55M and PON1-192Q [21-23], it should be remarked that there exists a differential activity of PON1-192Q genotype towards different substrates [51]. For that reason, besides genotypes, we analyzed all possible haplotypes and diplotype combinations as putative risk factors, and we explored all genetic association models. Our findings did not indicate association of the risk either with genotypes, allele frequencies, haplotypes or diplotypes.

A few previous reports addressed the possible role of PON1 polymorphisms in the risk for brain tumors: Searles-Nielsen et al. observed no main effects or interactions with insecticides for the Q192R and/or L55M SNPs, but suggested that the functional C-108T polymorphism and insecticide exposures may be important
[52,53] Kafadar et al. [54] studied PON1-Q192R polymorphism and serum PON1 activity in 42 patients with high grade gliomas, 42 patients with meningioma, and 50 controls. Although they found in both tumor groups decreased PON1 activity when compared with controls, PON1-Q192R genotype and allelic variants did not differ between the study groups. Rajamaran et al. [55] studied diverse gene polymorphisms related to oxidative response, including the PON1-Q192R polymorphism, in patients with glioma, meningioma, and acoustic neuroma. No association of the PON1-Q192R polymorphism with the risk of developing any of these tumors was identified.

In the present study we found no significant differences either in PON1-55 or PON1-192 allele frequencies or genotype frequencies between patients with meningioma or grade II/III astrocytoma, as compared with healthy control subjects.

A limitation of this study is that control subjects are younger than patients and that it cannot be ruled out that some control individuals would eventually develop brain tumors. Nevertheless, the possibility that some healthy subject would eventually develop these tumors in the lapse between the mean age of controls and the mean age of cases is negligible given the prevalence of these tumors in the studied population, and therefore the differences in the mean age of patients and controls reflects that the control group is not fully comparable to 
cases, but it should not influence the findings obtained in the present study. Regarding the geographical origin of the patients and controls, no genetic differences are expected because all participants were Spanish Caucasians living in close areas and because in previous genetic studies we have not detected any genetic differences between individuals from Extremadura and Madrid [56-60]. Another limitation of this study is the absence of data regarding exposure to chlorpyrifos or diazinon. Nevertheless, it should be stated that a recent study that identified interaction between exposure to insecticide treatment and some polymorphisms of pesticide metabolism genes failed to identify a significant interaction of exposure with the nonsynonymous PON1 polymorphisms analyzed in the present study [53]. Additional limitations are the inability to analyze other functional PON1 SNPs, such as the highly functional $\mathrm{C}-108 \mathrm{~T}$ SNP, and the lack of PON1 activity measurements, although this does not invalidate the findings indicating the lack of a major genetic association with the SNPs analyzed in this study. In fact, clinical association of PON1 polymorphisms, but not PON1 enzyme activity, with ischemic stroke has been recently demonstrated [61] and vice-versa, no association between adult brain tumors and PON1 genotype, but positive association with PON1 activity has been described [54]. In this regard, Furlong et al. recommend both, genotype determination and measurement of serum enzyme activity for evaluation of PON1's role in risk of disease or exposure [62].

Another limitation of this study is the sample size of subgroups of patients according to the histological type of tumor. In this study we cannot exclude a false negative result due to the sample size. Nevertheless, the study is sufficiently powered to rule out a major association of PON1 polymorphisms. For patients with astrocytoma the study can rule out an association with OR $\geq 2.1$, and for patients with meningioma the study can rule out an association with $\mathrm{OR} \geq 2.5$. Sporadic diseasegenotype associations this strong are extremely rare, particularly with cancer risk [63-65]. Even considering this limitation, this study indicates the absence of a major association of the nonsynonymous PON1 polymorphisms studied with brain tumors.

\section{Conclusions}

Common nonsynonymous PON1 polymorphisms are not related with the risk of developing astrocytoma and meningioma.

\section{Acknowledgements}

We are thankful to Gara Esguevillas for technical assistance. This work was financed by Grants PS09/00943, PS09/00469 and RETICS RD07/0064/0016 from Fondo de Investigación Sanitaria, Instituto de Salud Carlos III, Madrid, Spain and PRI07A005 from Junta de Extremadura, Mérida, Spain.

\section{Author details}

'Department of Pharmacology \& Psychiatry, Medical School, University of Extremadura, Badajoz, Spain. ${ }^{2}$ Service of Neurology, Hospital Doce de Octubre, Madrid, Spain. ${ }^{3}$ Department of Medicine-Neurology, Hospital "Príncipe de Asturias", Universidad de Alcalá, Alcalá de Henares, Madrid, Spain. "Section of Neurology, Hospital "La Mancha-Centro", Alcázar de San Juan, Ciudad Real, Spain. ${ }^{5}$ Department of Biochemistry and Molecular Biology and Genetics, University of Extremadura, Avda de Elvas s/n, 06071, Badajoz, Spain.

\section{Authors' contributions}

CM: acquisition of the data, critical revision, obtaining funding; administrative, technical and material support. JAM: acquisition of data; critical revision. HAN: conception and design, acquisition of the data, analysis and interpretation of the data, drafting of the submitted material, critical revision, administrative, technical and material support. FJJJ: conception and design, analysis and interpretation of the data, drafting of the submitted material, critical revision, administrative, technical and material support, and supervision. JAGA: conception and design, analysis and interpretation of the data, drafting of the submitted material, critical revision, statistical expertise, obtaining funding, and supervision. EGM: conception and design, analysis and interpretation of the data, drafting of the submitted material, critical revision, obtaining funding, and supervision.

All authors read and approved the final manuscript.

\section{Competing interests}

The authors declare that they have no competing interests.

Received: 15 December 2009 Accepted: 19 August 2010 Published: 19 August 2010

\section{References}

1. Parkin DM, Bray F, Ferlay J, Pisani P: Global cancer statistics, 2002. CA Cancer J Clin 2005, 55(2):74-108.

2. Inskip PD, Linet MS, Heineman EF: Etiology of brain tumors in adults. Epidemiol Rev 1995, 17(2):382-414.

3. De Roos AJ, Stewart PA, Linet MS, Heineman EF, Dosemeci M, Wilcosky T, Shapiro WR, Selker RG, Fine HA, Black PM, et al: Occupation and the risk of adult glioma in the United States. Cancer Causes Control 2003, 14(2):139-150.

4. Rajaraman P, De Roos AJ, Stewart PA, Linet MS, Fine HA, Shapiro WR, Selker RG, Black PM, Inskip PD: Occupation and risk of meningioma and acoustic neuroma in the United States. Am J Ind Med 2004, 45(5):395-407.

5. Khuder SA, Mutgi AB, Schaub EA: Meta-analyses of brain cancer and farming. Am J Ind Med 1998, 34(3):252-260.

6. Smith-Rooker JL, Garrett A, Hodges LC, Shue V: Prevalence of glioblastoma multiforme subjects with prior herbicide exposure. J Neurosci Nurs 1992, 24(5):260-264.

7. Carreon T, Butler MA, Ruder AM, Waters MA, Davis-King KE, Calvert GM, Schulte PA, Connally B, Ward EM, Sanderson WT, et al: Gliomas and farm pesticide exposure in women: the Upper Midwest Health Study. Environ Health Perspect 2005, 113(5):546-551.

8. Musicco M, Sant M, Molinari S, Filippini G, Gatta G, Berrino F: A case-control study of brain gliomas and occupational exposure to chemical carcinogens: the risk to farmers. Am J Epidemiol 1988, 128(4):778-785.

9. Ruder AM, Waters MA, Carreon T, Butler MA, Davis-King KE, Calvert GM, Schulte PA, Ward EM, Connally LB, Lu J, et al: The Upper Midwest Health Study: a case-control study of primary intracranial gliomas in farm and rural residents. J Agric Saf Health 2006, 12(4):255-274.

10. Provost D, Cantagrel A, Lebailly P, Jaffre A, Loyant V, Loiseau H, Vital A, Brochard P, Baldi I: Brain tumours and exposure to pesticides: a casecontrol study in southwestern France. Occup Environ Med 2007, 64(8):509-514.

11. Navas-Acien A, Pollan M, Gustavsson P, Plato N: Occupation, exposure to chemicals and risk of gliomas and meningiomas in Sweden. Am J Ind Med 2002, 42(3):214-227. 
12. Lee WJ, Colt JS, Heineman EF, McComb R, Weisenburger DD, Lijinsky W, Ward MH: Agricultural pesticide use and risk of glioma in Nebraska, United States. Occup Environ Med 2005, 62(11):786-792.

13. Schlehofer $B$, Hettinger I, Ryan P, Blettner M, Preston-Martin S, Little J, Arslan A, Ahlbom A, Giles GG, Howe GR, et al: Occupational risk factors for low grade and high grade glioma: results from an international case control study of adult brain tumours. Int J Cancer 2005, 113(1):116-125.

14. Samanic CM, De Roos AJ, Stewart PA, Rajaraman P, Waters MA, Inskip PD: Occupational exposure to pesticides and risk of adult brain tumors. Am J Epidemiol 2008, 167(8):976-985.

15. Qiao D, Seidler FJ, Slotkin TA: Developmental neurotoxicity of chlorpyrifos modeled in vitro: comparative effects of metabolites and other cholinesterase inhibitors on DNA synthesis in PC12 and C6 cells. Environ Health Perspect 2001, 109(9):909-913.

16. Guizzetti M, Pathak S, Giordano G, Costa LG: Effect of organophosphorus insecticides and their metabolites on astroglial cell proliferation. Toxicology 2005, 215(3):182-190.

17. Cowan J, Sinton CM, Varley AW, Wians FH, Haley RW, Munford RS: Gene therapy to prevent organophosphate intoxication. Toxicol Appl Pharmacol 2001, 173(1):1-6.

18. Humbert R, Adler DA, Disteche CM, Hassett C, Omiecinski CJ, Furlong CE: The molecular basis of the human serum paraoxonase activity polymorphism. Nat Genet 1993, 3(1):73-76.

19. Adkins S, Gan KN, Mody M, La Du BN: Molecular basis for the polymorphic forms of human serum paraoxonase/arylesterase: glutamine or arginine at position 191, for the respective A or B allozymes. Am J Hum Genet 1993, 52(3):598-608.

20. Mackness B, Mackness MI, Arrol S, Turkie W, Julier K, Abuasha B, Miller JE, Boulton AJ, Durrington PN: Serum paraoxonase (PON1) 55 and 192 polymorphism and paraoxonase activity and concentration in noninsulin dependent diabetes mellitus. Atherosclerosis 1998, 139(2):341-349.

21. Leviev I, Deakin S, James RW: Decreased stability of the M54 isoform of paraoxonase as a contributory factor to variations in human serum paraoxonase concentrations. J Lipid Res 2001, 42(4):528-535.

22. Mutch E, Daly AK, Williams FM: The Relationship between PON1 phenotype and PON1-192 genotype in detoxification of three oxons by human liver. Drug Metab Dispos 2007, 35(2):315-320.

23. Davies HG, Richter RJ, Keifer M, Broomfield CA, Sowalla J, Furlong CE: The effect of the human serum paraoxonase polymorphism is reversed with diazoxon, soman and sarin. Nat Genet 1996, 14(3):334-336.

24. Mackness MI, Mackness B, Durrington PN, Connelly PW, Hegele RA: biochemistry, genetics and relationship to plasma lipoproteins. Paraoxonase: Curr Opin Lipidol 1996, 7(2):69-76.

25. Mackness B, Durrington PN, Mackness Ml: The paraoxonase gene family and coronary heart disease. Curr Opin Lipidol 2002, 13(4):357-362.

26. Li HL, Liu DP, Liang CC: Paraoxonase gene polymorphisms, oxidative stress, and diseases. J Mol Med 2003, 81(12):766-779.

27. Shih DM, Gu L, Xia YR, Navab M, Li WF, Hama S, Castellani LW, Furlong CE, Costa LG, Fogelman AM, et al: Mice lacking serum paraoxonase are susceptible to organophosphate toxicity and atherosclerosis. Nature 1998, 394(6690):284-287

28. Barontini F, Sita D, Mennonna P: A case of cystic meningioma mimicking an astrocytoma. J Neurol 1982, 227(3):165-169.

29. Dario A, Marra A, Cerati M, Scamoni C, Dorizzi A: Intracranial meningioma and astrocytoma in the same patient. Case report and review of the literature. J Neurosurg Sci 1995, 39(1):27-35.

30. Davis GA, Fabinyi GC, Kalnins RM, Brazenor GA, Rogers MA: Concurrent adjacent meningioma and astrocytoma: a report of three cases and review of the literature. Neurosurgery 1995, 36(3):599-604, discussion 604595.

31. Gelabert Gonzalez M, Bollar Zabala A, Martinez Rumbo R, Garcia Allut A, Reyes Oliveros F: [Cerebral astrocytoma secondary to radiation of a meningioma]. Neurologia 1988, 3(2):68-70.

32. Horoupian DS, Lax F, Suzuki K: Extracerebral leptomeningeal astrocytoma mimicking a meningioma. Arch Pathol Lab Med 1979, 103(13):676-679.

33. Jenkinson MD, Javadpour M, du Plessis D, Shaw MD: Synchronous basal cell carcinoma and meningioma following cranial irradiation for a pilocytic astrocytoma. Br J Neurosurg 2003, 17(2):182-184.

34. Malhotra V, Beohar PC, Paul DN, Kumar S: Meningioma in association with astrocytoma-a case report. Indian J Cancer 1983, 20(1A):86-88.
35. Prayson RA, Chowdhary S, Woodhouse S, Hanson M, Nair S: Collision of a syncytial meningioma and malignant astrocytoma. Ann Diagn Pathol 2002, 6(1):44-48

36. Elexpuru-Camiruaga J, Buxton N, Kandula V, Dias PS, Campbell D, Mclntosh J, Broome J, Jones P, Inskip A, Alldersea J, et al: Susceptibility to astrocytoma and meningioma: influence of allelism at glutathione $\mathrm{S}$ transferase (GSTT1 and GSTM1) and cytochrome P-450 (CYP2D6) loci. Cancer Res 1995, 55(19):4237-4239.

37. Kumar R, Kamdar D, Madden L, Hills C, Crooks D, O'Brien D, Greenman J: Th1/Th2 cytokine imbalance in meningioma, anaplastic astrocytoma and glioblastoma multiforme patients. Oncol Rep 2006, 15(6):1513-1516.

38. Olivera M, Martinez C, Molina JA, Alonso-Navarro H, Jimenez-Jimenez FJ, Garcia-Martin E, Benitez J, Agundez JA: Increased frequency of rapid acetylator genotypes in patients with brain astrocytoma and meningioma. Acta Neurol Scand 2006, 113(5):322-326.

39. Kucukali Cl, Aydin M, Ozkok E, Orhan N, Cakir U, Kilic G, Ozbek Z, Ince N, Kara I: Paraoxonase-1 55/192 genotypes in schizophrenic patients and their relatives in Turkish population. Psychiatr Genet 2008, 18(6):289-294.

40. Garcia-Martin E, Martinez C, Alonso-Navarro H, Benito-Leon J, Puertas I, Rubio L, Lopez-Alburquerque T, Agundez JA, Jimenez-Jimenez FJ: Paraoxonase 1 (PON1) polymorphisms and risk for essential tremor. Eur J Neurol 2009, 17(6):879-81.

41. Martinez C, Garcia-Martin E, Benito-Leon J, Calleja P, Diaz-Sanchez M, Pisa D, Alonso-Navarro H, Ayuso-Peralta L, Torrecilla D, Agundez JA, JimenezJimenez FJ: Paraoxonase 1 Polymorphisms Are Not Related with the Risk for Multiple Sclerosis. Neuromolecular Med 2009.

42. Stephens M, Donnelly P: A comparison of bayesian methods for haplotype reconstruction from population genotype data. Am J Hum Genet 2003, 73(5):1162-1169.

43. Agundez JA, Golka K, Martinez C, Selinski S, Blaszkewicz M, Garcia-Martin E: Unraveling ambiguous NAT2 genotyping data. Clin Chem 2008, 54(8):1390-1394

44. Purcell S, Neale B, Todd-Brown K, Thomas L, Ferreira MA, Bender D, Maller J, Sklar P, de Bakker PI, Daly MJ, et al: PLINK: a tool set for whole-genome association and population-based linkage analyses. Am J Hum Genet 2007, 81(3):559-575.

45. el-Bacha RS, Minn A: Drug metabolizing enzymes in cerebrovascular endothelial cells afford a metabolic protection to the brain. Cell Mol Biol (Noisy-le-grand) 1999, 45(1):15-23.

46. Ravindranath $\mathrm{V}$ : Metabolism of xenobiotics in the central nervous system: implications and challenges. Biochem Pharmacol 1998, 56(5):547-551.

47. Cole TB, Jansen K, Park S, Li WF, Furlong CE, Costa LG: The Toxicity of Mixtures of Specific Organophosphate Compounds is Modulated by Paraoxonase 1 Status. Adv Exp Med Biol 2010, 660:47-60.

48. Jansen KL, Cole TB, Park SS, Furlong CE, Costa LG: Paraoxonase 1 (PON1) modulates the toxicity of mixed organophosphorus compounds. Toxicol Appl Pharmacol 2009, 236(2):142-153.

49. Infante-Rivard C, Weichenthal S: Pesticides and childhood cancer an update of Zahm and Ward's 1998 review. J Toxicol Environ Health B Crit Rev 2007, 10(1-2):81-99.

50. Zahm SH, Ward MH: Pesticides and childhood cancer. Environ Health Perspect 1998, 106(Suppl 3):893-908.

51. Li WF, Costa LG, Richter RJ, Hagen T, Shih DM, Tward A, Lusis AJ, Furlong CE: Catalytic efficiency determines the in-vivo efficacy of PON1 for detoxifying organophosphorus compounds. Pharmacogenetics 2000, 10(9):767-779.

52. Searles Nielsen S, Mueller BA, De Roos AJ, Viernes HM, Farin FM, Checkoway $\mathrm{H}$ : Risk of brain tumors in children and susceptibility to organophosphorus insecticides: the potential role of paraoxonase (PON1). Environ Health Perspect 2005, 113(7):909-913.

53. Nielsen SS, McKean-Cowdin R, Farin FM, Holly EA, Preston-Martin S, Mueller BA: Childhood brain tumors, residential insecticide exposure, and pesticide metabolism genes. Environ Health Perspect 2010, 118(1):144-149.

54. Kafadar AM, Ergen A, Zeybek U, Agachan B, Kuday C, Isbir T: Paraoxonase 192 gene polymorphism and serum paraoxonase activity in high grade gliomas and meningiomas. Cell Biochem Funct 2006, 24(5):455-460.

55. Rajaraman P, Hutchinson A, Rothman N, Black PM, Fine HA, Loeffler JS, Selker RG, Shapiro WR, Linet MS, Inskip PD: Oxidative response gene polymorphisms and risk of adult brain tumors. Neuro Oncol 2008, 10(5):709-715. 
56. Martinez C, Garcia-Martin E, Ladero JM, Sastre J, Garcia-Gamito F, DiazRubio M, Agundez JA: Association of CYP2C9 genotypes leading to high enzyme activity and colorectal cancer risk. Carcinogenesis 2001, 22(8):1323-1326.

57. Martinez C, Martin F, Fernandez JM, Garcia-Martin E, Sastre J, Diaz-Rubio M, Agundez JA, Ladero JM: Glutathione S-transferases mu 1, theta 1, pi 1, alpha 1 and mu 3 genetic polymorphisms and the risk of colorectal and gastric cancers in humans. Pharmacogenomics 2006, 7(5):711-718.

58. Garcia-Martin E, Mendoza JL, Martinez C, Taxonera C, Urcelay E, Ladero JM, de la Concha EG, Diaz-Rubio M, Agundez JA: Severity of ulcerative colitis is associated with a polymorphism at diamine oxidase gene but not at histamine N-methyltransferase gene. World I Gastroenterol 2006, 12(4):615-620.

59. Blanco G, Martinez C, Ladero JM, Garcia-Martin E, Taxonera C, Gamito FG, Diaz-Rubio M, Agundez JA: Interaction of CYP2C8 and CYP2C9 genotypes modifies the risk for nonsteroidal anti-inflammatory drugs-related acute gastrointestinal bleeding. Pharmacogenet Genomics 2008, 18(1):37-43.

60. Oliver J, Agundez JA, Morales S, Fernandez-Arquero M, FernandezGutierrez B, de la Concha EG, Diaz-Rubio M, Martin J, Ladero JM: Polymorphisms in the transforming growth factor-beta gene (TGF-beta) and the risk of advanced alcoholic liver disease. Liver Int 2005, 25(5):935-939.

61. Demirdogen BC, Demirkaya S, Turkanoglu A, Bek S, Arinc E, Adali O: Analysis of paraoxonase 1 (PON1) genetic polymorphisms and activities as risk factors for ischemic stroke in Turkish population. Cell Biochem Funct 2009, 27(8):558-567.

62. Furlong CE, Suzuki SM, Stevens RC, Marsillach J, Richter RJ, Jarvik GP, Checkoway H, Samii A, Costa LG, Griffith A, et al: Human PON1, a biomarker of risk of disease and exposure. Chem Biol Interact 2010.

63. Wacholder S, Chanock S, Garcia-Closas M, El Ghormli L, Rothman N: Assessing the probability that a positive report is false: an approach for molecular epidemiology studies. J Natl Cancer Inst 2004, 96(6):434-442.

64. Agundez JA: Polymorphisms of human $\mathrm{N}$-acetyltransferases and cancer risk. Curr Drug Metab 2008, 9(6):520-531.

65. Agundez JA: Cytochrome P450 gene polymorphism and cancer. Curr Drug Metab 2004, 5(3):211-224.

\section{Pre-publication history}

The pre-publication history for this paper can be accessed here: http://www.biomedcentral.com/1471-2377/10/71/prepub

doi:10.1186/1471-2377-10-71

Cite this article as: Martínez et al:: Two common nonsynonymous paraoxonase 1 (PON1) gene polymorphisms and brain astrocytoma and meningioma. BMC Neurology 2010 10:71.

\section{Submit your next manuscript to BioMed Central and take full advantage of:}

- Convenient online submission

- Thorough peer review

- No space constraints or color figure charges

- Immediate publication on acceptance

- Inclusion in PubMed, CAS, Scopus and Google Scholar

- Research which is freely available for redistribution

Submit your manuscript at www.biomedcentral.com/submit
Biomed Central 